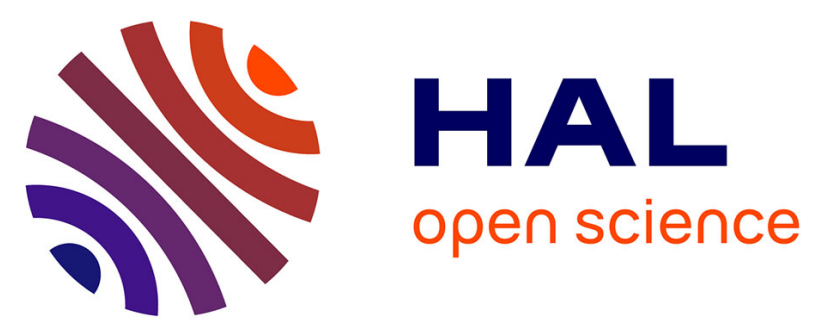

\title{
Effectiveness and complications of ultrasound-guided subclavian vein cannulation in children and neonates
}

Nicolas Nardi, Eric Wodey, Bruno Laviolle, François de La Brière, Séverine

Delahaye, Charlotte Engrand, Cécile Gauvrit, Sabrina Dessard, Anne

Defontaine, Claude Ecoffey

\section{To cite this version:}

Nicolas Nardi, Eric Wodey, Bruno Laviolle, François de La Brière, Séverine Delahaye, et al.. Effectiveness and complications of ultrasound-guided subclavian vein cannulation in children and neonates. Anaesthesia Critical Care \& Pain Medicine, 2016, 35 (3), pp.209-213. 10.1016/j.accpm.2015.09.007. hal-01281520

HAL Id: hal-01281520

https://hal-univ-rennes1.archives-ouvertes.fr/hal-01281520

Submitted on 8 Jun 2016

HAL is a multi-disciplinary open access archive for the deposit and dissemination of scientific research documents, whether they are published or not. The documents may come from teaching and research institutions in France or abroad, or from public or private research centers.
L'archive ouverte pluridisciplinaire HAL, est destinée au dépôt et à la diffusion de documents scientifiques de niveau recherche, publiés ou non, émanant des établissements d'enseignement et de recherche français ou étrangers, des laboratoires publics ou privés. 


\section{Accepted Manuscript}

Title: Effectiveness and complications of ultrasound-guided subclavian vein cannulation in children and neonates $<$ !- $<$ RunningTitle $>$ Ultrasound-guided subclavian vein cannulation $<$ /RunningTitle $>->$

Author: Nicolas Nardi Eric Wodey Bruno Laviolle François

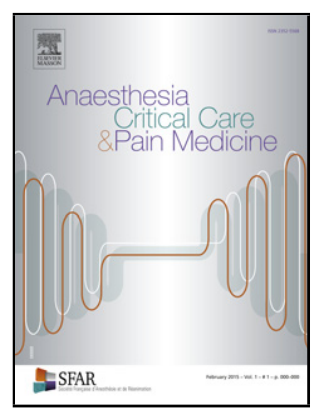
De La Brière Séverine Delahaye Charlotte Engrand Cécile Gauvrit Sabrina Dessard Anne Defontaine Claude Ecoffey

PII: $\quad$ S2352-5568(16)00024-2

DOI: $\quad$ http://dx.doi.org/doi:10.1016/j.accpm.2015.09.007

Reference: $\quad$ ACCPM 118

To appear in:

Received date: $\quad 15-4-2015$

Revised date: 25-9-2015

Accepted date: $\quad$ 28-9-2015

Please cite this article as: Nicolas NardiEric WodeyBruno LaviolleFrançois De La BrièreSéverine DelahayeCharlotte EngrandCécile GauvritSabrina DessardAnne DefontaineClaude Ecoffey Effectiveness and complications of ultrasound-guided subclavian vein cannulation in children and neonates $<!-$ $<$ RunningTitle $>$ Ultrasound-guided subclavian vein cannulation $<$ RunningTitle $>->$ (2016), http://dx.doi.org/10.1016/j.accpm.2015.09.007

This is a PDF file of an unedited manuscript that has been accepted for publication. As a service to our customers we are providing this early version of the manuscript. The manuscript will undergo copyediting, typesetting, and review of the resulting proof before it is published in its final form. Please note that during the production process errors may be discovered which could affect the content, and all legal disclaimers that apply to the journal pertain. 
Effectiveness and complications of ultrasound-guided subclavian vein cannulation in children and neonates

Nicolas Nardi, MD ${ }^{1,2,3}$, Eric Wodey, MD, $\mathrm{PhD}^{1,2,3}$, Bruno Laviolle, MD, PhD ${ }^{2,4}$, François De La Brière, $M D^{1}$, Séverine Delahaye, $M D^{1}$, Charlotte Engrand, $M D^{1}$, Cécile Gauvrit, $M D^{1}$, Sabrina Dessard, $\mathrm{MD}^{1}$, Anne Defontaine, $\mathrm{MD}^{1}$, Claude Ecoffey, $\mathrm{MD}, \mathrm{PhD}^{1,2}$

\section{Received from:}

1 CHU de Rennes, Service d'anesthésie réanimation 2, F-35203, Rennes, France.

2 Université de Rennes 1, F-35000, Rennes, France

3 UMR INSERM 1099, LTSI, Université de Rennes 1, Rennes, France.

${ }^{4} \mathrm{CHU}$ de Rennes, Centre d'investigation clinique; Service de pharmacologie, Rennes, France.

Running title: Ultrasound-guided subclavian vein cannulation

The authors report no conflicts of interest in relation to this article.

Address correspondence to Dr. Nicolas Nardi: Pôle Samu Urgence Anesthésie Réanimation, Hôpital Sud, 16, boulevard Bulgarie, 35203 Rennes cedex 2, France.

e-mail: nicolas.nardi@chu-rennes.fr

\section{Abstract}

Background: The ultrasound (US)-guided supraclavicular approach to subclavian vein (SupSCV) catheterisation in children has recently been described and evaluated in a small cohort. 
The aim of this study was to assess this technique in a large paediatric cohort including neonates.

Methods: We conducted a prospective observational study between November 2010 and December 2013 which included 615 children divided into two groups according to their weight: Group $1 \leq 5 \mathrm{~kg}(n=124)$, Group $2>5 \mathrm{~kg}(n=491)$. All procedures were performed under general anaesthesia by an anaesthesiologist or a supervised resident. The success rates of catheter insertion, the number of punctures required, the procedure time, and the complication rates were analysed.

Results: Sup-SCV catheterisation was successful in $98 \%$ of the cases and was higher in Group 2 than in Group $1(99.4 \%$ versus $92.7 \%, P<0.001)$. The success rate after the first attempt was higher and the incidence of multiple attempts ( $\geq 3$ punctures) was lower in Group 2 than in Group 1( $84.2 \%$ versus $64.5 \%, P<0.001$ and $4.5 \%$ versus $19.4 \%$, $P<0.001)$. The success rate was similar between right and left cannulations $(P=0.404)$, and according to physician experience $(P=1.000)$. Procedure time was fast in both groups with a median time for all procedures of 40 [30-90] seconds. Among the procedures recorded, only five arterial punctures and no cases of pneumothorax were observed.

Conclusion: US-guided Sup-SCV catheterisation appears to be fast and safe in children and neonates, even if it remains a little more difficult to achieve in lower-weight patients.

\section{Introduction}

Central venous catheter insertion is a routine act in paediatric anaesthesia and intensive care which can be associated with mechanical complications such as arterial puncture, haematoma, pneumothorax and malposition or failure of cannulation. [1] The use of ultrasound (US) facilitates and secures this medical act and is now widely used. [2-5] Internal jugular vein (IJV) catheterisation is the gold standard but remains difficult in infants weighing $<10 \mathrm{~kg},[6]$ and exposes the patient to a higher risk of infection compared with subclavian vein catheterisation. $[7,8]$ Recently, a new method for a US-guided supraclavicular approach to 
the subclavian vein (Sup-SCV) in children has been described $[9,10]$ and evaluated on a small cohort of children. [11-14]

We therefore performed a 3-year prospective, observational study to assess the effectiveness and morbidity of this technique in a large cohort of children and neonates.

\section{Methods}

\section{Study population}

This prospective, single-centre, non-randomised, observational study was conducted from November 2010 to December 2013 at the University Hospital of Rennes, France. After approval by the local Institutional Review Board ( ${ }^{\circ} 15.57$ ), a computerised prospective registry of all central venous cannulation in children seen in the operating theatre was performed.

An US-guided technique for supraclavicular cannulation was used for all central venous lines required for children. The only exclusion criterion was the inability to visualize the SCV correctly but this situation was not encountered. The cohort was empirically divided into two groups according to weight: Group $1 \leq 5 \mathrm{~kg}$, Group $2>5 \mathrm{~kg}$.

\section{Procedure}

We used three types of catheters: short-term catheters (Seldiflex®, Prodimed), long-term tunneled open-ended catheters (Broviac ${ }^{\circledR}$ catheter, Bard), or venous implantable ports (Polysite $®$, Perouse). The diameters and lengths of the catheters were calculated according to the patient's weight

All catheters were placed using ultrasound machines manufactured by General Electric Logic $\mathrm{e}^{\circledR}$ or Venue $40^{\circledR}$ with a high frequency "hockey stick" probe, at respectively $10 \mathrm{MHz}$ and 18MHz. We used a sterile cover specially designed for US devices (Pull up ${ }^{\circledR}$, Protek Medical). All procedures were performed in the operating theatre under general anaesthesia after tracheal intubation in the supine position with a Trendelenburg tilt. We used a standard-sized towel rolled under the child's shoulders with his/her head slightly turned to the opposite of the cannulation side. The operator sat on the cannulation side with the US device on the other 
side. All catheterisations were performed under aseptic surgical conditions. After transversal identification of the internal jugular vein and carotid artery at mid-cervical level, the vessels were traced in the caudal direction with the US probe. Once the probe was in the supraclavicular fossa, small movements in the caudal direction enabled visualization of the confluence of the internal jugular vein and subclavian vein in its longitudinal axis.

When a satisfactory image in the longitudinal axis of the vessel was obtained, the needle was introduced in the same axis as the probe. In this way, the needle without an attached syringe could be inserted under full vision into the vein. If spontaneous blood flashback was obtained, the end of the procedure was carried out using Seldinger's technique. If no spontaneous blood return was observed despite clear positioning of the needle bevel in the vessel lumen on US, a syringe was attached to the needle hub to aspirate blood and then the guide wire was introduced into the vein. If blood could not be aspirated, the needle was withdrawn and another attempt was made.

During the procedure, we used fluoroscopy to confirm that the guide wire was in the superior vena cava. The end of the procedure was defined by the correct positioning of the guide wire in the superior vena cava. In the recovery room, a chest X-ray was carried out to confirm the proper position of the catheter tip and to exclude any procedure complications.

\section{Data collection}

The following data were recorded: age, weight, operator experience (resident or anaesthesiologist), indication, the device used, catheter size, side of catheterisation, procedure duration (i.e. time in seconds between the first needle puncture and the end-ofguide placement), the number of punctures required to correctly insert the guide wire and complications (guide wire malposition, arterial puncture, haematoma, or pneumothorax). Study endpoints

The aims of the study were to assess the success rates of catheter insertion, the number of punctures needed, procedure time, and complication rates. The success rates were also assessed between right and left cannulations and for residents versus anaesthesiologists. 
Catheterisation failure was defined by the need to puncture another vein, including the contralateral Sup-SCV or to change operators to correctly insert the catheter.

Statistical Methods

Statistical analysis was performed with SAS Software version 9.2 (SAS Institute, Cary, NC, USA). Data are presented as medians (first-third quartiles) for continuous variables and as numbers with the corresponding percentages for qualitative variables. Comparisons between groups were performed using Student's t-tests or Wilcoxon rank sum tests as appropriate for continuous variables, and chi-square or Fisher exact tests as appropriate for categorical variables. Statistical significance was defined as $P<0.05$.

\section{Results}

During the 3-year study period, 615 procedures using the Sup-SCV approach were recorded in the database. The characteristics of the patients and devices used are summarized in Table 1. The children were aged from 0 to18 years and their weights ranged from $1.2 \mathrm{~kg}$ to $94 \mathrm{~kg}$. There were 124 patients in Group 1 (median weight: 3.3kg) and 491 patients in Group 2 (median weight: 17kg). Twenty residents and nine anaesthesiologists performed the catheterisations.

The study endpoints are summarized in Table 2. Overall, the ultimate success rate, i.e. the rate of successful placement of the central venous catheter in the primarily targeted vein without changing operators, was $98 \%$ and was higher in Group 2 compared with Group 1. (Relative risk: $11.9,95 \%$ confidence interval [3.3; 43.2], $P<0.001$ ). The success rate after the first attempt was higher and the incidence of multiple attempts ( $\geq 3$ punctures) was lower in Group 2 compared with Group 1 (relative risks: 2.2, 95\% confidence interval [1.3; 3.0], $P<0.001$, and $0.91,95 \%$ confidence interval $[0.85 ; 0.98], P<0.001$, respectively). Procedure success rates were similar between right and left cannulations $(97.6 \%$ with right SCV and $98.6 \%$ with left SCV, $P=0.404$ ), as well as according to physician experience (98.1\% for residents and $98.0 \%$ for anaesthesiologists, $P=1.000)$. The duration of the procedure was significantly longer in lower-weight infants $(+13 \%, P=0.007)$. Catheterisation 
failure occurred 12 times. Table 3 summarizes patient characteristics and the causes of failure.

Among the complications recorded, arterial punctures tended to be more frequent in Group 1 compared with Group 2 (relative risk, 5.6, 95\% confidence interval [1.0; 35.2], $P=0.058$ ). No occurrences of pneumothorax were observed.

\section{Discussion}

In the present paediatric cohort encompassing 615 procedures, we demonstrated that the Sup-SCV approach was successful in $98 \%$ of cases $(81.4 \%$ on the first attempt) with a short procedure time and a low rate of complications (2.9\%).

To the best of our knowledge, this is the largest prospective observational study evaluating US-guided Sup-SCV catheterisation performed in children.

Our results are consistent with previously published paediatric studies on this technique (Table 4 ) that showed success rates ranging from $97.6 \%$ to $100 \%(65.3 \%$ to $82.9 \%$ after one attempt) [10-14] and early complication rates ranging from $0 \%$ to $4.7 \%$ ( 1 arterial puncture $[11,13]$ and 1 pneumothorax [13]).

Weight is an important element in the interpretation of results and makes comparison of studies difficult. In the present study, a very low body weight $(\leq 5 \mathrm{~kg})$ was associated with a lower success rate (92.7\%; especially as concerns first attempts $(64.5 \%)$ ), a greater incidence of multiple attempts (13\%), longer procedure times and a higher complication rate $(5.7 \%)$. In a retrospective study that included 183 children $(<10 \mathrm{~kg})$ with 89 neonates (< $3.6 \mathrm{~kg}$ ), Breshan et al. [12] also found that the probability of puncture success and the number of attempts depended on weight. They had a $79.8 \%$ puncture success rate after one attempt but only $72 \%$ in the neonate group.

In the present series, the success rate of the procedure did not significantly differ between right and left cannulations, regardless of the group studied. The distribution between left and right sides was almost equal and identical in each group. This result is not in agreement with the retrospective study by Breshan et al. [12] who suggested that cannulation side was an independent factor of puncture success in favour of the left side $(82.9 \%$ versus $38.4 \%$ 
success after one attempt and $77.2 \%$ versus $30 \%$ in the neonate group). The main limit of their study was the large disparity in numbers for left and right cannulations with, as the first choice of their operators, the left side. Conversely, our results are consistent with the study by Rhondali et al. [11], which included 37 children (median weight: $4.1 \mathrm{~kg}$ ), who reported $81 \%$ puncture success on the first attempt with 27 right cannulations.

Finally, the US-guided Sup-SCV technique appears to be a fast and safe approach for obtaining central venous access even in lower-weight children. In this study, the short duration of the procedure could be explained by different factors. The operator's location was ergonomic, thereby providing good hand-eye coordination. The position at the patient's shoulder enabled the operator to sit with the US screen in front of him. The hand manipulating the probe could be placed on the patient's chest, providing some stability during cannulation attempts. It also appeared to be easy to make the needle progress into the vein without an attached syringe. The Trendelenburg tilt and mechanical ventilation prevented the risk of air embolism. The "hockey stick" probe placed in the supra-clavicular fossa obtained a longitudinal view of the venous target and the entire pathway to it. The pleural fascia was then easily identified, which could explain why no cases of pneumothorax were observed with the sup SCV approach since the beginning of the registry.

The US-guided Sup-SCV technique is easy to teach and all of the anaesthesiologists and residents in our department are now using this approach. In our cohort, the success rate was similar between the residents and the anaesthesiologists and only two failures could have been related to the operator's experience (patients 5 and 9). The anaesthesiologist introduced the catheter just after the failure of the resident with the same approach and on the same side.

The US-guided Sup-SCV approach is also an interesting alternative to other techniques. No study has compared US-guided Sup-SCV and IJV catheterisation in children. However, although the success rates for the US-guided IJV approach in children are high (between $80 \%$ and $100 \%)[3,4,14-19]$, success rates on the first attempt appear to be lower with this technique. A recent prospective trial of US-guided versus Landmark-guided IJV access in the 
paediatric population including 150 patients (mean weight: $27 \mathrm{~kg}$ ) reported only $65 \%$ (with US-guided) and 45\% (with Landmark-guided) success on the first attempt [5]. Moreover, USguided IJV catheterisation exposes the patient to a higher risk of infection compared with subclavian vein catheterisation $[7,8]$.

US-guided Sup-SCV and Infraclavicular(Inf)-SCV approaches were compared in children in one prospective randomised study that included 98 children (mean weight: $7.2 \mathrm{~kg}$ ) [14]. This study was in favour of the Sup-SCV approach with a decrease of the incidence of multiple attempts (> 3$)(6.1 \%$ versus $24.5 \%)$ and guide-wire misplacements ( $0 \%$ versus $20.4 \%)$. In addition, with the US-guided Inf-SCV approach [20], needle visualization is interrupted during its path under the clavicle toward the subclavian vein and there is a risk of catheter damage or breakage by costoclavicular pinching if the catheter is left in place for a long time [21].

This study has several potential limitations. First, it must be emphasized that this was a single-centre, observational study. Second, short-, medium- and long-term complications such as infection or thrombosis were not addressed. It is possible that improvements in the time taken to obtain venous access and a low number of punctures and procedure complications are associated with a fall in the incidence of later morbidity. To address this issue, a prospective follow-up of paediatric central catheters is on-going in our department. In conclusion, the Sup-SCV appears to be a fast and safe approach for obtaining central venous access in children and neonates, even if it remains a little more difficult to achieve in low-weight patients. A randomised trial would be interesting in order to assess the best USguided technique between an in-plane Sup-SCV approach and an out-of-plane IJV approach in neonates and premature infants [22]. 


\section{References}

1. Schummer W, Schummer C, Rose N, Niesen WD, Sakka SG. Mechanical complications and malpositions of central venous cannulations by experienced operators. A prospective study of 1794 catheterizations in critically ill patients. Intensive Care Med 2007;33:1055-9.

2. Excellence NIfC. Guidance on the use of ultrasound locating devices for placing central venous catheters. Technology Appraisal Guidance $N^{\circ} 49$ Septembre 2002:www.nice.org.uk.

3. Hind D, Calvert N, McWilliams R, Davidson A, Paisley S, Beverley C, Thomas S. Ultrasonic locating devices for central venous cannulation: meta-analysis. BMJ 2003;327:361.

4. Sigaut S, Skhiri A, Stany I, Golmar J, Nivoche Y, Constant I, Murat I, Dahmani S. Ultrasound guided internal jugular vein access in children and infant: a meta-analysis of published studies. Paediatr Anaesth 2009;19:1199-206.

5. Bruzoni M, Slater BJ, Wall J, St Peter SD, Dutta S. A prospective randomized trial of ultrasound- vs landmark-guided central venous access in the pediatric population. $\mathrm{J}$ Am Coll Surg 2013;216:939-43.

6. Morita M, Sasano H, Azami T, Sasano N, Fujita Y, Ito S, Sugiura T, Sobue K. A novel skin-traction method is effective for real-time ultrasound-guided internal jugular vein catheterization in infants and neonates weighing less than 5 kilograms. Anesth Analg 2009;109:754-9.

7. Breschan C, Platzer M, Jost R, Schaumberger F, Stettner H, Likar R. Comparison of catheter-related infection and tip colonization between internal jugular and subclavian central venous catheters in surgical neonates. Anesthesiology 2007;107:946-53.

8. Citak A, Karabocuoglu M, Ucsel R, Uzel N. Central venous catheters in pediatric patients--subclavian venous approach as the first choice. Pediatr Intern 2002;44:83-6.

9. Attof R, Rhondali O, Combet S, Chassard D, De Queiroz M. Abord de la veine sousclavière par voie sus-claviculaire sous échographie: une nouvelle approche en pédiatrie. Ann Fr Anesth Reanim 2010;29:651-4.

10. Breschan C, Platzer M, Jost R, Stettner H, Beyer AS, Feigl G, Likar R. Consecutive, prospective case series of a new method for ultrasound-guided supraclavicular approach to the brachiocephalic vein in children. Br J Anaesth 2011;106:732-7. 
11. Rhondali O, Attof R, Combet S, Chassard D, de Queiroz Siqueira M. Ultrasoundguided subclavian vein cannulation in infants: supraclavicular approach. Paediatr Anaesth 2011;21:1136-41.

12. Breschan C, Platzer M, Jost R, Stettner H, Feigl G, Likar R. Ultrasound-guided supraclavicular cannulation of the brachiocephalic vein in infants: a retrospective analysis of a case series. Paediatr Anaesth 2012;22:1062-7.

13. Guilbert AS, Xavier L, Ammouche C, Desprez P, Astruc D, Diemunsch P, Bientz J. Supraclavicular ultrasound-guided catheterization of the subclavian vein in pediatric and neonatal ICUs: a feasibility study. Pediatr Crit Care Med 2013;14:351-5.

14. Byon HJ, Lee GW, Lee JH, Park YH, Kim HS, Kim CS, Kim JT. Comparison between ultrasound-guided supraclavicular and infraclavicular approaches for subclavian venous catheterization in children--a randomized trial. Br J Anaesth 2013;111:788-92.

15. Alderson PJ, Burrows FA, Stemp LI, Holtby HM. Use of ultrasound to evaluate internal jugular vein anatomy and to facilitate central venous cannulation in paediatric patients. Br J Anaesth 1993;70:145-8.

16. Verghese ST, McGill WA, Patel RI, Sell JE, Midgley FM, Ruttimann UE. Ultrasoundguided internal jugular venous cannulation in infants: a prospective comparison with the traditional palpation method. Anesthesiology 1999;91:71-7.

17. Verghese ST, McGill WA, Patel RI, Sell JE, Midgley FM, Ruttimann UE. Comparison of three techniques for internal jugular vein cannulation in infants. Paediatr Anaesth 2000;10:505-11.

18. Asheim $P$, Mostad $U$, Aadahl $P$. Ultrasound-guided central venous cannulation in infants and children. Acta Anaesthesiol Scand 2002;46:390-2.

19. Leyvi G, Taylor DG, Reith E, Wasnick JD. Utility of ultrasound-guided central venous cannulation in pediatric surgical patients: a clinical series. Paediatr Anaesth2005;15:953-8.

20. Pirotte T, Veyckemans F. Ultrasound-guided subclavian vein cannulation in infants and children: a novel approach. Br J Anaesth 2007;98:509-14.

21. Caruselli M, Zannini R, Giretti R, Piattellini G, Bechi P, Ventrella F, et al. The pinch-off syndrome in a pediatric patient. Paediatr Anaesth 2009;19:179-81. 
22. Arul GS, Livingstone H, Bromley P, Bennett J. Ultrasound-guided percutaneous insertion of 2.7 Fr tunnelled Broviac lines in neonates and small infants. Pediat Surg Intern= 2010;26:815-8. 
Table 1: Patient characteristics and devices used.

\begin{tabular}{|c|c|c|c|c|}
\hline & $\begin{array}{l}\text { Total } \\
(n=615)\end{array}$ & $\begin{array}{l}\text { Group } 1(\leq 5 \mathrm{~kg}) \\
(n=124)\end{array}$ & $\begin{array}{l}\text { Group } 2(>5 \mathrm{~kg}) \\
(n=491)\end{array}$ & $P$ \\
\hline Sex (male/female) & $369(60) / 246(40)$ & $72(58) / 52(42)$ & $297(60) / 194(40)$ & 0.622 \\
\hline Age (months) & $33[6-111]$ & $1[0-2]$ & $59[17-133]$ & $<0.001$ \\
\hline Weight (kg) & $14[7-27]$ & $3.3[2.7-4.0]$ & $17[10-3$ & $<0.001$ \\
\hline \multicolumn{5}{|l|}{ CVC indication } \\
\hline Antibiotherapy & $116(19)$ & 19(15) & $97(20)$ & 0.259 \\
\hline Surgery & $170(28)$ & $49(40)$ & $121(25)$ & $<0.001$ \\
\hline Chemotherapy & $202(33)$ & $3(2)$ & $199(40)$ & $<0.001$ \\
\hline Parenteral nutrition & $51(8)$ & $26(21)$ & $25(5)$ & $<0.001$ \\
\hline Medical treatment & $74(12)$ & $27(22)$ & $49(10)$ & $<0.001$ \\
\hline Device used & & & & $<0.001$ \\
\hline Short-term & $382(62)$ & $111(90)$ & $271(55)$ & \\
\hline Tunneled catheter & $136(22)$ & $13(10)$ & $123(25)$ & \\
\hline Venous implantable Port & $97(16)$ & $0(0)$ & $97(20)$ & \\
\hline Catheter diameter (French) & $4.2[4-5]$ & $3[3-3]$ & $5[4-6]$ & $<0.001$ \\
\hline Side (right/left) & $337(55) / 278(45)$ & $65(52) / 59(48)$ & $272(55) / 219(45)$ & 0.552 \\
\hline Resident / anaesthesiologist & $158(26) / 457(74)$ & $19(15) / 105(85)$ & $139(28) / 352(72)$ & 0.003 \\
\hline
\end{tabular}

Results are expressed as medians [interquartile ranges] or numbers (\%) of total patients in each group. CVC: central venous catheter 
Table 2: Comparison of the study endpoints

\begin{tabular}{lllll}
\hline & Total & Group 1 $(\leq 5 \mathrm{~kg})$ & Group 2 (>5 kg) & $P$ \\
& $(n=615)$ & $(n=124)$ & $(n=491)$ & \\
\hline Success of the procedure & $603(98.1)$ & $115(92.7)$ & $488(99.4)$ & $<0.001$ \\
Success on first attempt & $491(79.8)$ & $80(64.5)$ & $411(84.2)$ & $<0.001$ \\
Multiple attempts $(\geq 3)$ & $46(7.5)$ & $24(19.4)$ & $22(4.5)$ & $<0.001$ \\
Cannulation times $(s)$ & $40[30-90]$ & $45[30-180]$ & $40[30-90]$ & 0.007 \\
Complications & $18(2.9)$ & $7(5.6)$ & $11(2.2)$ & 0.067 \\
Arterial puncture & $5(0.8)$ & $3(2.4)$ & $2(0.4)$ & 0.058 \\
Haematoma & $2(0.3)$ & $1(0.8)$ & $1(0.2)$ & 0.363 \\
Guide wire malposition & $11(1.8)$ & $3(2.4)$ & $8(1.6)$ & 0.470
\end{tabular}

Results expressed as medians [interquartile ranges] or numbers (\%) of total patients in each group. 
Table 3: Catheterisation failure: patient characteristics and cause of failure. 


\begin{tabular}{|c|c|c|c|c|c|c|}
\hline Patient & $\begin{array}{l}\text { Date of } \\
\text { procedure }\end{array}$ & Weight & Indication $1 \mathrm{I}$ & $\begin{array}{l}\text { Site of } \\
\text { failure }\end{array}$ & Cause of failure & Solution \\
\hline 1 & $12 / 05 / 2010$ & 19 & Chemotherapy & Right & $\begin{array}{l}\text { Guide wire } \\
\text { could not be } \\
\text { inserted in the } \\
\text { vein }\end{array}$ & $\begin{array}{l}\text { Right IJV } \\
\text { immediately } \\
\text { during the } \\
\text { same } \\
\text { anaesthetic act }\end{array}$ \\
\hline 2 & 07/07/2010 & 2.5 & $\begin{array}{l}\text { Parenteral } \\
\text { nutrition }\end{array}$ & Right & $\begin{array}{l}\text { Guide wire } \\
\text { could not be } \\
\text { inserted in the } \\
\text { vein }\end{array}$ & $\begin{array}{l}\text { Right Sup SCV } \\
15 \text { days later }\end{array}$ \\
\hline 3 & $25 / 08 / 2010$ & 14 & Chemotherapy & Right & $\begin{array}{l}\text { Guide wire } \\
\text { malposition }\end{array}$ & $\begin{array}{l}\text { Right IJV } \\
\text { immediately } \\
\text { during the } \\
\text { same } \\
\text { anaesthetic act }\end{array}$ \\
\hline 4 & $28 / 09 / 2010$ & 2.6 & $\begin{array}{l}\text { Parenteral } \\
\text { nutrition }\end{array}$ & Right & $\begin{array}{l}\text { Guide wire } \\
\text { could not be } \\
\text { inserted in the } \\
\text { vein }\end{array}$ & $\begin{array}{l}\text { Left Sup-SCV } \\
\text { immediately } \\
\text { during the } \\
\text { same } \\
\text { anaesthetic act }\end{array}$ \\
\hline 5 & $02 / 12 / 2010$ & 62 & Chemotherapy & Right & Teaching & $\begin{array}{l}\text { Right Sup-SCV } \\
\text { immediately } \\
\text { during the } \\
\text { same } \\
\text { anaesthetic act }\end{array}$ \\
\hline 6 & 07/01/2011 & 2 & Surgery & Left & $\begin{array}{l}\text { Guide wire } \\
\text { malposition }\end{array}$ & $\begin{array}{l}\text { Left IJV } \\
\text { immediately } \\
\text { during the } \\
\text { same } \\
\text { anaesthetic act }\end{array}$ \\
\hline 7 & $29 / 07 / 2011$ & 4 & $\begin{array}{l}\text { Medical } \\
\text { treatment }\end{array}$ & Left & $\begin{array}{l}\text { Anatomic } \\
\text { abnormality }\end{array}$ & $\begin{array}{l}\text { Right Sup SCV } \\
\text { ten days[c1] } \\
\text { afterwards }\end{array}$ \\
\hline 8 & $12 / 11 / 2011$ & 2 & $\begin{array}{l}\text { Parenteral } \\
\text { nutrition }\end{array}$ & Right & $\begin{array}{l}\text { Guide wire } \\
\text { could not be } \\
\text { inserted in the } \\
\text { vein }\end{array}$ & $\begin{array}{l}\text { Left Sup SCV } \\
15 \text { days } \\
\text { afterwards }\end{array}$ \\
\hline 9 & $18 / 12 / 12$ & 2.7 & $\begin{array}{l}\text { Medical } \\
\text { treatment }\end{array}$ & Left & Teaching & $\begin{array}{l}\text { Left Sup-SCV } \\
\text { immediately } \\
\text { during the } \\
\text { same } \\
\text { anaesthetic act }\end{array}$ \\
\hline 10 & $13 / 03 / 2013$ & 3.1 & Surgery & Right & $\begin{array}{l}\text { Guide wire } \\
\text { malposition }\end{array}$ & $\begin{array}{l}\text { Right femoral } \\
\text { immediately } 15 \\
\text { during the } \\
\text { same } \\
\text { anaesthetic act }\end{array}$ \\
\hline
\end{tabular}


Table 4: Summary of studies published on US-guided Sup-SCV in paediatric populations

\begin{tabular}{|c|c|c|c|}
\hline Author & Patients $(n)$ & Weight (kg) & Results \\
\hline $\begin{array}{l}\text { Breschan et al. } \\
{[10]}\end{array}$ & 35 & $\begin{array}{l}\text { median } \\
6.75\end{array}$ & $\begin{array}{l}\text { Success rate } 100 \% \\
\text { first attempt } 73.8 \% \\
\text { No major complications }\end{array}$ \\
\hline $\begin{array}{l}\text { Rhondali et al. } \\
\text { [11] }\end{array}$ & 37 & $\begin{array}{l}\text { median } \\
4.1\end{array}$ & $\begin{array}{l}\text { Success rate } 100 \% \\
\text { first attempt } 81 \% \\
\text { Major complications: } \\
1 \text { arterial puncture }\end{array}$ \\
\hline $\begin{array}{l}\text { Breschan et al. } \\
\text { [12] }\end{array}$ & 183 & $\begin{array}{l}\text { median } \\
3.7\end{array}$ & $\begin{array}{l}\text { Success rate: } 98.9 \% \\
\text { first attempt } 82.9 \% \\
\text { No major complications: } \\
\text { Easier to cannulate the left BCV }\end{array}$ \\
\hline $\begin{array}{l}\text { Guilbert et al. } \\
\text { [13] }\end{array}$ & 42 & $\begin{array}{l}\text { median } \\
6.5\end{array}$ & $\begin{array}{l}\text { Success rate: } 97.6 \% \\
\text { Major complication: } \\
\qquad \begin{array}{c}1 \text { arterial puncture } \\
1 \text { pneumothorax }\end{array}\end{array}$ \\
\hline Byon et al. [14] & 49 & $\begin{array}{l}\text { mean } \\
7.3\end{array}$ & $\begin{array}{l}\text { Success rate } 100 \% \\
\text { first attempt } 65.3 \% \\
\text { No major complications }\end{array}$ \\
\hline
\end{tabular}

